Neuroepidemiology 2002;21:310

DOI: $10.1159 / 000065530$

\section{Is Interferon Effective and Safe for Relapsing-Remitting Multiple Sclerosis?}

Graziella Filippini, Barbara Incorvaia, on behalf of the Cochrane Neurological Network

\section{Question}

Is interferon effective and safe to prevent multiple sclerosis relapses and disease progression?

\section{Data Source}

Cochrane systematic review of randomized controlled trials [1]. Trials were identified by searching Medline (1966-2000), Embase (1988-2000), Central (Cochrane Library, issue 4, 2000), and handsearching abstract proceedings of the main multiple sclerosis symposia in Europe and America.

\section{Patients}

Patients with relapsing-remitting multiple sclerosis in remission.

\section{Treatment}

Interferon-beta 1a (Avonex, Rebif), 6-12 MIU, administered 1-3 times weekly by the intramuscular or subcutaneous route, and interferon-beta-1b (Betaferon), 1.6-16 MIU, self-administered every other day or 3 times weekly subcutaneously.

Table 1. Benefit and risk of recombinant interferon treatment in multiple sclerosis

\begin{tabular}{|c|c|c|c|c|c|}
\hline $\begin{array}{l}\text { Events/ } \\
\text { treatment }\end{array}$ & $\begin{array}{l}\text { Events/ } \\
\text { placebo }\end{array}$ & OR & $95 \% \mathrm{CI}$ & $\begin{array}{l}\text { ARR, } \\
\%\end{array}$ & $\begin{array}{l}\text { NNT or } \\
\text { NNH }\end{array}$ \\
\hline \multicolumn{6}{|c|}{ Relapse within 1 year } \\
\hline $\begin{array}{l}166 / 332 \\
(50 \%)\end{array}$ & $\begin{array}{l}229 / 335 \\
(68 \%)\end{array}$ & 0.44 & $0.32-0.61^{1}$ & 18 & 5 \\
\hline \multicolumn{6}{|c|}{ Relapse at 2 years } \\
\hline $\begin{array}{l}257 / 466 \\
(55 \%)\end{array}$ & $\begin{array}{l}315 / 453 \\
(69 \%)\end{array}$ & 0.52 & $0.39-0.69$ & 14 & 7 \\
\hline \multicolumn{6}{|c|}{ Progression at 2 years } \\
\hline $\begin{array}{l}92 / 466 \\
(20 \%)\end{array}$ & $\begin{array}{l}131 / 453 \\
(29 \%)\end{array}$ & 0.61 & $0.45-0.83$ & 9 & 11 \\
\hline \multicolumn{6}{|c|}{ Flu-like syndrome } \\
\hline $\begin{array}{l}269 / 564 \\
(48 \%)\end{array}$ & $\begin{array}{l}157 / 553 \\
(28 \%)\end{array}$ & 2.31 & $1.81-2.96$ & 19 & 5 \\
\hline
\end{tabular}

$\mathrm{OR}=$ Odds ratio $; \mathrm{ARR}=$ absolute risk reduction $; \mathrm{NNT}$ or $\mathrm{NNH}=$ number needed to treat or to harm.

1 Significant heterogeneity among the trials.

\section{Outcome Measures}

(1) The number of patients who continued to experience exacerbations during the scheduled follow-up period. (2) The number of patients who progressed (Expanded Disability Status Scale) during the first 2 years. (3) The number of patients experiencing side effects or adverse events.

\section{Quality of the Studies}

The evaluated trials had substantial methodological inadequacies in allocation concealment, high proportion and incomplete description of dropouts and failure to adhere to the principles of intentionto-treat analysis. Because of prominent treatment-associated side effects, which could be easily identified by patients, these trials could be considered as single-blind rather than double-blind.

\section{Main Results}

1,215 patients were included in the review, but only $919(76 \%)$ contributed to these results. Interferon significantly reduced the occurrence of relapses within 1 year and at 2 years and disability progression at 2 years (table 1). However, if interferon-treated patients without follow-up evaluation were considered to have disability progression (worst case scenario), the OR was not significant $(\mathrm{OR}=1.52 ; 95 \% \mathrm{CI}, 1.16-2.00)$. A flu-like syndrome was more frequent in treated patients than in controls.

\section{Conclusion}

The authors found a modest effect of the treatment in reducing exacerbations and disability. Because of the poor methodological quality of the trial reports, they concluded that there is not clear, convincing durable effect of interferons on disability in patients with relapsing-remitting multiple sclerosis.

Comment

Despite convincing evidence that interferon treatment is effective in preventing exacerbation in relapsing-remitting multiple sclerosis, clinical practice indicates that only a few eligible patients are receiving durable treatment. The most commonly cited reasons [1] for interferon discontinuation are concerns about side effect and maintenance of long-term medication.

This review provides a concise balance sheet of potential benefits and risks associated with interferon treatment. Five patients needed to be treated to prevent one of them from developing an increase in disability, whereas in one case an additional flu-like syndrome occurred after the treatment of these 5 patients. The acceptability of the risk/benefit ratio should be evaluated on a case-by-case basis.

Given the substantial cost of interferon treatment, these are important questions of large clinical relevance.

\section{Reference}

1 Rice G, Incorvaia B, Munari L, Ebers G, Polman C, D’Amico R, Filippini $\mathrm{G}$ : Interferon in relapsing-remitting multiple sclerosis; in: Cochrane Library, Issue 4, 2001. Update Software.

\begin{tabular}{ll}
\hline KARGER & ( ) 2002 S. Karger AG, Basel \\
0251-5350/02/0216-0271\$18.50/0 \\
$\begin{array}{l}\text { Fax +4161306 12 34 } \\
\begin{array}{l}\text { E-Mail karger@karger.ch } \\
\text { www.karger.com }\end{array}\end{array}$ & $\begin{array}{l}\text { Accessible online at: } \\
\text { www.karger.com/journals/ned }\end{array}$
\end{tabular}

Dr. Graziella Filippini

Cochrane Neurological Network, Dipartimento di Scienze Neurologiche

Via F. Sforza, 35

I-20122 Milano (Italy)

E-Mail cochrane.neuronet@unimi.it, Website: http://www.cochraneneuronet.org 